\title{
Integration through Peers - A Study on the Integration of Migrant Children in Pupil Networks in four German Secondary Schools
}

${ }^{1}$ Dipl.-Geogr. Philipp Aufenvenne, ${ }^{2}$ Jun. Prof. Dr. Miriam Kuckuck, ${ }^{1}$ MA Nina Leimbrink, ${ }^{1}$ BA Max Pochadt, ${ }^{1}$ Prof. Dr. Malte Steinbrink

${ }^{1}$ Osnabrück University, Institute for Geography, Seminarstraße 19ab 49074 Osnabrück - Germany ${ }^{2}$ Bergische Universität Wuppertal, School of Social and Human Sciences, Institute for Geographie Gaußstraße 2042119 Wuppertal - Germany

\section{ABSTRACT}

This paper deals with the integration of migrant children in informal communication networks in four diffenrent schools in Germany. The basic assumption is that these networks can serve as an indicator for the networking and embedding that take place within the class community and therefore can be used to investigate the integration of pupils with a migrant background. The initial results of our network analytical study reveal that the pupils with a migrant background are well integrated into the class networks. The study discloses that the migrant background does not serve as a conclusive characteristic of the pattern of class networks. The pupils are more or less networked with each other regardless of their migrant background, though it did emerge that children and adolescents born abroad, in particular, are far more likely to have outgoing relationships that remain unreciprocated.

Keywords: network analysis, social integration, school research, peer groups

\section{Acknowledgement:}

We acknowledge support by Deutsche Forschungsgemeinschaft (DFG) and Open Access Publishing Fund of Osnabrück University.
*Correspondence to Author:

Dipl.-Geogr. Philipp Aufenvenne 1Osnabrück University, Institute for Geography, Seminarstraße 19ab 49074 Osnabrück - Germany

How to cite this article:

Philipp Aufenvenne,Miriam Kuckuck, Nina Leimbrink, Max Pochadt, Malte Steinbrink. Integration through Peers - A Study on the Integration of Migrant Children in Pupil Networks in four German Secondary Schools. American Journal of Educational Research and Reviews, 2018,3:19.

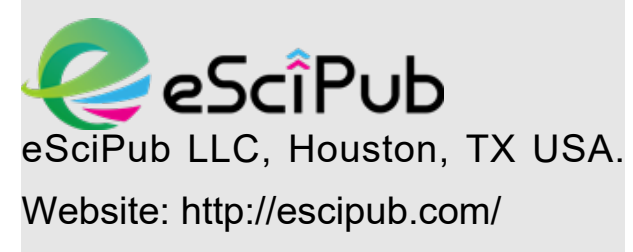




\section{Introduction: The integrative dual function of the school}

In the school year 2016/17 in Germany, the number of pupils climbed again across the country for the first time in almost 20 years. Contrary to all previous forecasts, current estimates indicate that the increase in the number of school children is set to continue (Klemm \& Zorn, 2017). While this can, in part, be traced back to years characterised by high birth rates, it is the large number of newly arrived immigrant children, in particular, that serves as a reason for the upward trend (DESTATIS 2017). A lively debate about school-based integration is currently taking place against the backdrop of these developments. Hardly any other topic attracts similarly high levels of attention in ongoing education policy discussions. The main issue at the centre of this debate is the question of how the integration of newly arrived schoolchildren at schools may be achieved. Often, the debates are linked to the results of international learning progress surveys. In this context, studies such as PISA and TIMSS have shown that a considerable number of adolescents fail to achieve the expected competences of their age group (Ceri 2008, Deutsches PISA Konsortium 2001, OECD 2007, EURYDICE 2004). As early on as 2010, Quenzel and Hurrelmann (p.11) lamented that close to $8 \%$ of a given cohort leave school without graduating, and nearly one pupil in ten performs below the lowest level of competences in the PISA evaluation of reading skills. Among these, young males from educationally disadvantaged homes represented the group most severely affected by educational poverty. This tendency intensifies even further in cases with a migrant background: "Foreign adolescents are twice as likely to leave school without graduating than German adolescents" (Quenzel \& Hurrelmann, 2010, p. 14; our translation).

In the sphere of education policy, the social "integration problem" is often countered with the phrase "integration through education" (BMBF 2015). The package promoted consists of support measures and operationalisation instruments such as educational standards, core curricula and the like, with the aim to improve the school performances of (migrant) schoolchildren (cf. Trappmann, 2003). The overall objective is to ease social integration, primarily comprehended as economic participation, in other words, by means of improving opportunities offering access to the labour market. For this purpose, the focus is firmly placed on formal education with insufficient consideration being given to the fact that classroom education is by far not the only place where educational processes are initiated, as these are also known to occur in the family and the peer group (cf. Harring, 2010, p. $21 \mathrm{ff}$.). This phenomenon is referred to as informal education or socialisation, where especially the interactions among peers bear an extraordinary significance for nearly all aspects of the personality development of children and adolescents (Trappmann, 2003; Reitz et al., 2014). For the purpose of this paper, the term peers refers to children and adolescents of approximately the same age, who have (friendly) relations with each other and depend on each other for mutual orientation, thus acting as central entities of socialisation and education (cf. Harring et al., 2010). Within the framework of the (informal and less hierarchical) peer-to-peer interaction, children and adolescents can experiment with forms of behaviour and communication and can acquire essential social competences in a space other than the family and the traditional, highly formalised lesson situation (cf. Betz, 2004, p. 19; Krappmann, 2010, p. 189). In this context, Böhm-Kasper et al. (cf. 2010, p. 14) emphasise that migrant children and adolescents often benefit from better opportunities to achieve greater linguistic proficiency through contacts and interactions with peers without a migrant background; in turn, language skills serve as an essential prerequisite both for success in school and for social integration (cf. Böhm-Kasper et al., 2010., p. 14). The authors assert: 
"Social relations represent central frames of reference for every individual, with important functions not merely in terms of integration into the (sub-)society but also with regard to recognition, wellbeing and reflexive selfassurance" (Böhm-Kasper et al., 2010, p. 9; our translation).

The school represents the key space for initiating and exercising social contacts (cf. Preuss-Lausitz, 1992, p. 9; Trappmann, 2003, p. $57 \mathrm{ff}$.). As a place where children and adolescents regularly come together and spend much time in each other's company, the school offers ideal conditions to encourage the development of social ties to fellow pupils (cf. Zeiher \& Zeiher, 1994). Classmates often become friends, with interactions taking place not only within the school but also, by mutual agreement, for joint leisure time activities outside of the school context (cf. Büchner, 1994; Krappmann \& Oswald, 1983). As a result, the school serves as a spatial hub or, respectively, as "core of the childhood network of relationships" (Büchner, 1994, p. 17) and thus, simultaneously, as a link connecting formal and informal education (cf. Harring, 2010, p. 56).

Consequently, for children and adolescents with a migrant background, the school can fulfil two integrative functions: On the one hand, the integration through formal education and on the other hand, the integration through informal education by means of networks of fellow pupils. Here, the school provides the social and spatial arena for everyday informal contacts and interactions. This second, informal function of integration performed by the school represents the starting point of the research project, which gave rise to this paper.

Following the German Sociologist Esser (2006, p. 7), we understand social integration to mean "the inclusion (or exclusion) of actors in an existing social system". For the purpose of our study, the social system is the school class, as this provides not only the context in which formal education processes occur, but also the central site and occasion for the emergence, maintenance and consolidation of important social relations between the pupils (cf. Parsons, 1970). As social integration refers to "differences between the individual actors in terms of the scope of the relations they maintain and in terms of the degree of the individually distinctive social embeddedness of the individual actors" (Esser, 2001, p. 5; our translation), the social embeddedness of migrant school children in informal communication, interaction and contact networks in class communities represents an appropriate indicator for (everyday) social integration. Accordingly, in our project, we conduct a comparative analysis across classes and age groups, both of the structures of the social ties within each class and also of the positions of migrant pupils within these networks. As such, this paper introduces a viable and innovative methodological approach to a highly relevant topic in terms of school, education and social policy.

The central question of the study is as follows

To what extent are migrant schoolchildren of the school grades 5-10 integrated in the structures of informal class communities? Is their social embeddedness different from that of pupils from the "majority society"? Does the so-called migrant background actually play a role in the structuring of class networks?

This paper is the first publication to emerge from this relatively young research project. We would therefore like to start by describing the underlying research design and explaining the process of data collection. In the next step, initial results are presented with reference to the central research question. Further and in-depth analyses will follow as the project progresses.

\section{Methodological process and description of the underlying data}

A network analytical approach lends itself particularly well to the investigation of the integration of migrant pupils in the informal communication and contact structures of their school classes. A Social Network Analysis 
(SNA) commonly serves to analyse so-called overall networks. On a general level, these are defined as a previously limited amount of social actors (nodes) and specific relationships (edges/relations) that exist between them (Mitchell 1969, p. 2). This definition applies well to school classes: School classes can be clearly delimited: It is clearly defined who belongs to the class communities, and who does not. What is more, numerous social ties exist between peers in the sphere of the school which can be captured for the purpose of network analysis (cf. Bicer et al., 2014). Thus, SNA offers a sound methodological option for concretizing the understanding of integration in line with Esser (2006) and operationalising it empirically.

The development of the network analytical research design and the subsequent data collection took place within the scope of a research training seminar at Osnabrück University's Department of Geography which was supported by the EKBI Initiative (Expertise and Cooperation for a Basic Qualification in Inclusion $)^{1}$. Working in collaboration with nine students, a questionnaire was developed and tested during the period from October 2016 to January 2017. The data collection took place in cooperation with four schools located in Osnabrück (two grammar schools, one integrated comprehensive school and one middle school) and was conducted during the lesson time. In total, data were collected from 39 regular classes in grades 5 to 10. After adjusting the sample, data from a total of 940 school children were available for the analysis. The pupils were asked about their social relationships within their respective class community. The questions covered different kinds of school and non-school contacts (breaktime contacts, party invitations, visiting each other at home, sharing a room during a school trip, social media contacts, leisure time contacts, discussions of problems and group work). For the purpose of the initial analyses, we treated these relationships as equivalent and initially concentrated solely on producing a quantitative evaluation. Every school child had the option of listing any number of fellow pupils from his or her own class for each of the relationships. Details of the ties were gathered by means of closed questions. For instance, questions included: "Who from your class would you invite to your party?" The school children interviewed then had the option to tick the respective fellow pupils, or to select them from a list. The collected data were subsequently anonymized. In addition to gathering these relational data, personal attributes of the interviewees were also surveyed (country of birth, parents' country of birth, age, sex, native language(s), resident in Germany since, and so on). Furthermore, the respective class teachers received a questionnaire, which comprised further attributes (e.g. performance level of the pupils). The present paper focuses exclusively on the aspect of "migrant background". Other variables (relevant to integration) such as "length of stay", "language skills", or "performance level" shall be considered in future stages of analysis.

The discussion about the social political meaningfulness and discursive efficacy of the label "migrant background" is set aside for the purpose of this paper, for the benefit of allowing simple connectivity to the political integration discourse in Europe and escpecially in Germany. Thus, we define the migrant background in line with the Federal Statistical Office of Germany. According to this, a person has "[...] a migrant background if this person or at least one parent was not born a German citizen." (DESTATIS, 2011, p. 26; our translation). Moreover, we distinguish between migrant background of the first and the second generation: children and adolescents of the second generation were themselves born in Germany, while at least one parent was born

\footnotetext{
For further details on the EKBI project please refer to the project website at URL: https://www.uni-
} 
outside of Germany. In contrast, those of the first generation were themselves not born in Germany. In the sample we surveyed, $55 \%$ of the pupils had no migrant background, $32 \%$ were migrant children and adolescents of the second generation, and $13 \%$ had a migrant background of the first generation (see Table 1).

Accordingly, the composition of our sample corresponds very closely to that of the overall body of school children in Osnabrück: There, $54 \%$ have no migrant background, $33 \%$ have a migrant background of the second generation and $13 \%$ have a migrant background of the first generation (City of Osnabrück, 2017, n. p.).

The network data gathered were evaluated with the support of the network analysis programmes UCINet (Borgatti et al., 2009) and Gephi (Bastian, et al., 2009). In the following, we present the initial results from the research project.

\section{Initial results}

In order to address the question about the extent to which school children are integrated in the peer-to-peer context at school, we first examined how well they were integrated in the network context of their respective class community compared to pupils without a migrant background. The calculation of degree centrality is an appropriate network analytical tool that lends itself to this task. "Degree centrality illustrates the sum of relations which one actor has to other actors in the network" (Steinbrink et al., 2013, p. 46, our translation). Consequently, this determination allows conclusions to be drawn about the (social) activity and thus indicates, to some extent, the sociability and popularity of the school children within their class. The survey deployed recorded directional relationships; for instance, one school girl listed one or more pupils in the relationship "problem discussion" (outgoing relationships); regarded from the other direction, the same school girl was also named by others as a counterpart when dealing with problems (incoming relationships). The sum of incoming relations is labelled indegree, while the sum of the outgoing relations is referred to as the outdegree of an actor. Considering the average outdegree of school children without migrant background of the first and the second generation across all eight surveyed types of relationships, it is possible to determine differences in the levels of network activity (see Table 1): On average, the pupils without a migrant background have 31.6, those of the second generation have 28.18, and those of the first generation have 23.33 outgoing relationships.

Nonetheless, it is important to point out at this point that the network activity of these three groups only differs on a statistically significant level between the school children without a migrant background and those born abroad ( $1^{\text {st }}$ generation). At first glance, this result does not appear surprising. The low average value of the group born abroad may certainly be traced back, in part, to their shorter length of stay within the class community.

The outdegree, on the other hand, is somewhat limited in its suitability for capturing the social embeddedness within the class, as it represents solely the own network activity of each pupil. It therefore follows that it is feasible that individual pupils may list numerous fellow school children as social contacts, while they themselves are not named at all. In order to determine the embeddedness more accurately, it is thus necessary to include the incoming relations, in particular in the evaluation and furthermore, to pay special attention to the mutual relationships. Insights about their reciprocal network connections can be of significant value, particularly when considering the issue of the integration of individual pupils, as reciprocity forms the foundation for trusting and stable social relationships (cf. Stegbauer, 2002).

For the next stage of the analysis we consequently drew exclusively on the mutual relationships and among these we concentrated solely on considering those contacts that can be assigned to at least four different types of 
relationship (for instance, contact during break time, party invitations, visiting each other's homes, and group work). This definition is based on the assumption that reciprocal relationships of this intensity are of special relevance for the peer-to-peer interaction, as they indicate closer social ties, in other words, strong ties.

The school children without a migrant background have an average of 2.67 reciprocal relationships, those of the second generation have 2.32, and those of the first generation have 1.56 (see Table 1). Hence, the differences that can be observed between the three groups with regard to their embeddedness are more obvious here than when contemplating the outdegree (see above). It can be stated that the school children with a migrant background are, on average, less strongly embedded within the class community than their counterparts without a migrant background.

This leads us to the next question, which considers with whom the pupils establish their relationships. How pronounced are the ties between pupils with and without a migrant background? Do the class networks acknowledge the characteristic of "migrant background" in their patterns?

In order to address this question, SNA offers the option to measure homophily. Homophily refers to the propensity of actors to establish relations to each other when they are alike in regard to a particular characteristic, i.e., when they share the same attribute (e.g. the same gender or the same origin) (McPherson et al., 2001). Figure 1 depicts all 39 class networks. A simple glance at the network patterns suffices to reveal that the attribute of having a migrant background displays a strikingly uneven distribution. There are some classes that are composed (almost) entirely of pupils with a migrant background, but at the same time, there are other classes, where very few migrant pupils are taught. Of course, the sample also includes classes with evenly distributed shares.

Figure 1 also illustrates that many school children with a migrant background have numerous contacts to pupils without a migrant background. Furthermore, it is possible to detect a trend indicating that those pupils born abroad seem to occupy rather peripheral positions in the networks in terms of numbers - though this result is somewhat ambiguous. Consequently, from a purely visual perspective, it is not possible to determine any unequivocal patterns in relation to the attribute "migrant background", which could be interpreted as indicative of homophily.

Table 1 presents the number of ties between and within the three groups. The significant variations in the values are primarily the result of the different group sizes. In order to measure homophily, the ties within the groups are related to the outgoing contacts in the next step. If the so-called E-I Index ${ }^{2}$ is between -0.5 and -1 , it is considered appropriate to speak of a pronounced homophily of the network.

The cross tabulation (Table 1) results in an E-I Index value of -0.177 . This means that, from an overall perspective, the class networks studied feature either no homophily or very little homophily with regard to the attribute "migrant background". Hence, it follows that pupils with and without a migrant background do not display more pronounced internal networks among each other than with members of the respective groups characterised by other attributes. However, a careful inspection of all ties reveals that pupils born abroad seem to have noticeably more outgoing than incoming relationships with the other groups. In relation to school children without a migrant background there are 1,013 outgoing ties, while only 709 connections are recorded for the other direction. In terms of connecting to pupils with a migrant background of the second generation, there are 1,245 outgoing compared to only 984 incoming relationships. This result appears to be of

2 The E-I Index (External-Internal Index) serves as a simple calculation for the degree of embeddedness of groups. The value 


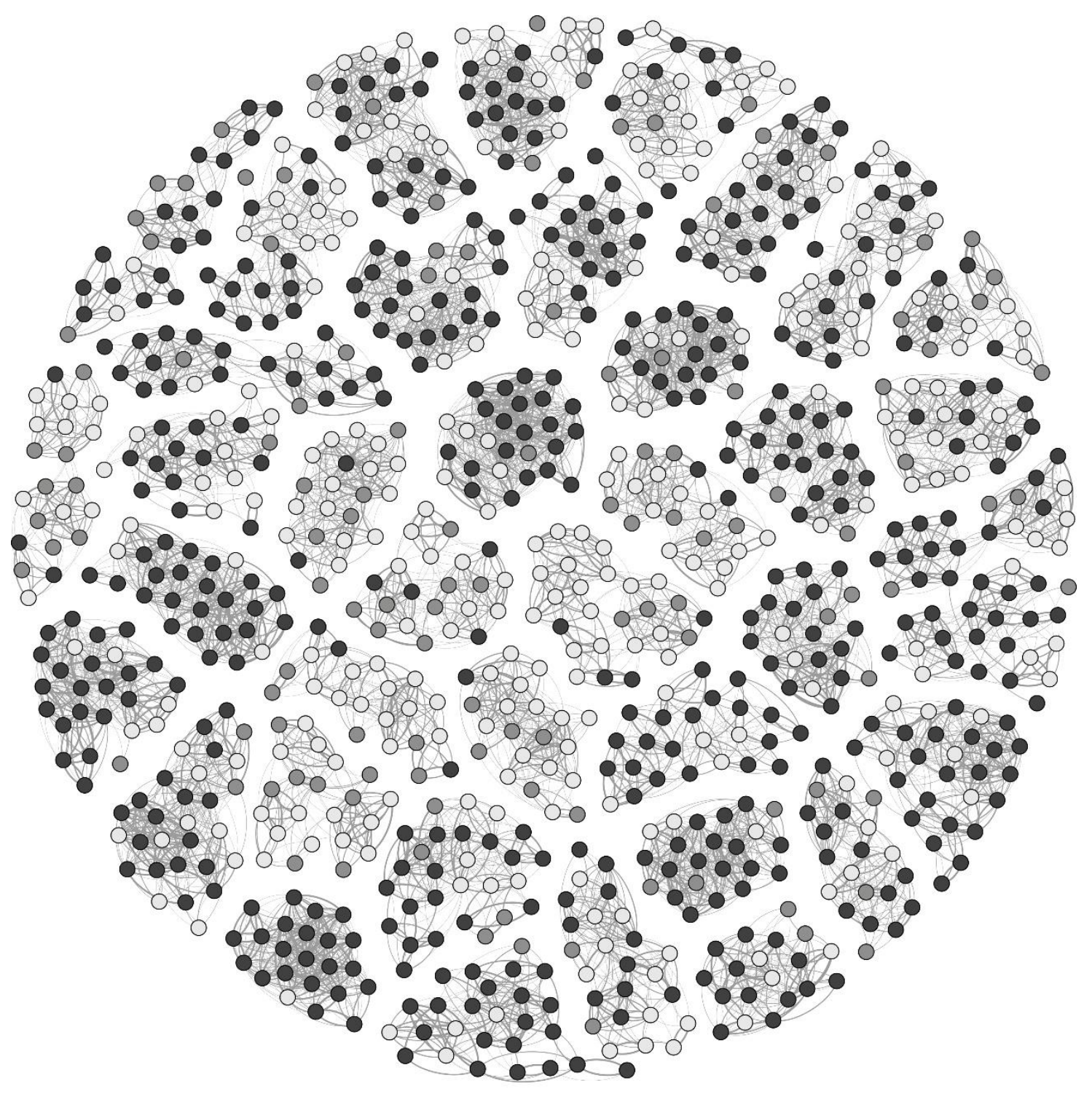
pupils without
migrant background
pupils with migrant background
of the $2^{\text {nd }}$ generation

pupils with migrant background
of the $1^{\text {st }}$ generation

$\cap$ social ties between pupils

Figure 1: Class networks with an illustration of the migrant background (own depiction; the visualisation is based on the Fruchtermann-Reingold algorithm, cf. Fruchtermann \& Reingold 1991)

Table 1: Shares and distribution of the relationships between the pupils by migrant background for all schools and classes (overall view; own survey)

\begin{tabular}{|c|c|c|c|c|c|c|c|}
\hline \multirow{5}{*}{$\begin{array}{c}55 \% \\
\text { (520 pupils) }\end{array}$} & \multirow{3}{*}{$\begin{array}{c}13 \% \\
\text { (119 pupils) }\end{array}$} & \multicolumn{6}{|c|}{ Schools in total(940 pupils) } \\
\hline & & $\begin{array}{c}\text { E-I Index } \\
-0.177\end{array}$ & $\begin{array}{c}\text { without } \\
\text { migrant } \\
\text { background }\end{array}$ & $\begin{array}{c}\text { migrant } \\
\text { background } \\
2^{\text {nd }} \\
\text { generation }\end{array}$ & $\begin{array}{c}\text { migrant } \\
\text { background } \\
1^{\text {st }} \\
\text { generation }\end{array}$ & $\begin{array}{l}\text { outdegree } \\
\varnothing \text { per pupil }\end{array}$ & $\begin{array}{c}\text { reciprocal } \\
\text { ties } \\
\text { above } 3 \\
\varnothing \text { per pupil }\end{array}$ \\
\hline & & $\begin{array}{c}\text { without } \\
\text { migrant } \\
\text { background }\end{array}$ & 12157 & 3.564 & 709 & 31.6 & 2.67 \\
\hline & \multirow[t]{2}{*}{$\begin{array}{c}32 \% \\
\text { (301 pupils) }\end{array}$} & $\begin{array}{c}\text { migrant } \\
\text { background } \\
2^{\text {nd }} \\
\text { generation }\end{array}$ & 3869 & 3.629 & 984 & 28.18 & 2.32 \\
\hline & & $\begin{array}{c}\text { migrant } \\
\text { background } \\
1^{\text {st }} \\
\text { generation }\end{array}$ & 1013 & 1.245 & 518 & 23.33 & 1.56 \\
\hline
\end{tabular}

http://escipub.com/american-journal-of-educational-research-and-reviews/ 
interest, insofar as the values should be reasonably balanced if the migrant background truly had no significance. However, care should be taken when opting for this interpretation: It is conceivable that the result may also be influenced by the fact that there are often very few pupils with a migrant background of the first generation in any particular class, and that these, more or less automatically, have increased relations (by necessity) with the pupils from the other groups. Within the other two groups, a somewhat greater range of choice is available.

Based on the analyses performed to date it can be stated that while the migrant background or, Grammar school I

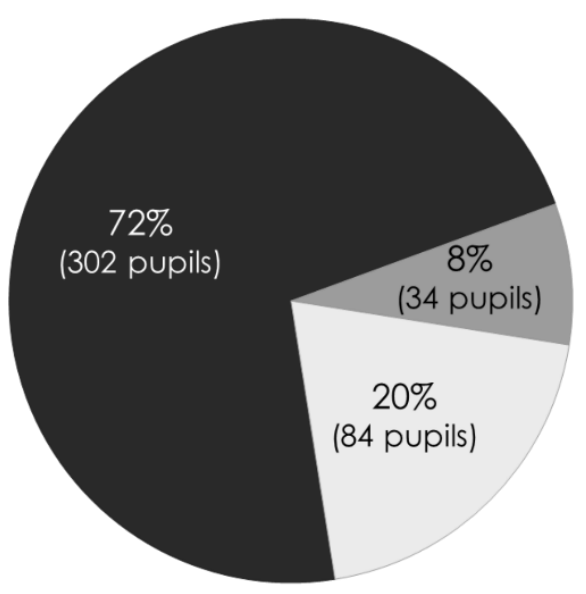

Grammar school II

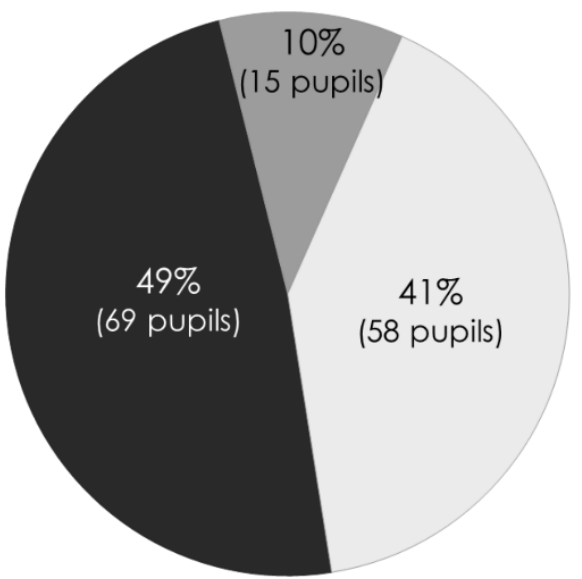

pupils without

migrant background

pupils with migrant background

of the $1^{\text {st }}$ generation respectively, the manifestation thereof, does bear significance in terms of the number and the selection of social contacts within school classes, this significance does not appear to be very pronounced.

Nonetheless, as mentioned above, Figure 1 clearly reveals that the attribute of "migrant background" features a highly uneven distribution across the classes. This discrepancy becomes even more apparent when the values are compared at the level of the schools. Figure 2 depicts the distribution of the school children with a migrant background across the four schools investigated.

\section{Comprehensive school}

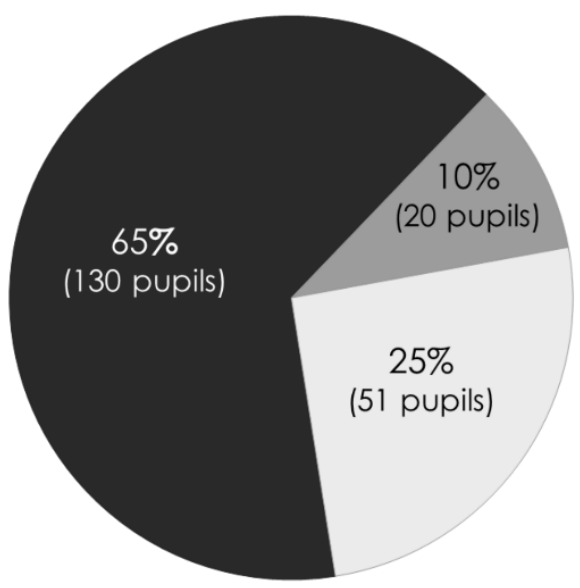

Middle school

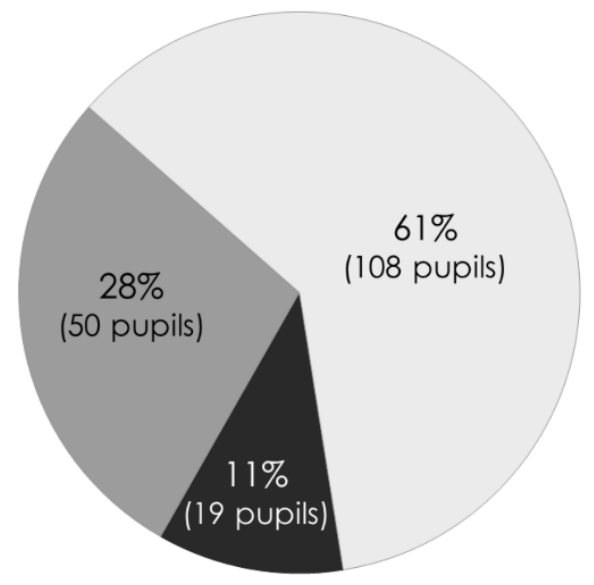

pupils with migrant background of the $2^{\text {nd }}$ generation

Figure 2: Distributions of pupils by migrant background at the level of schools (own survey) http://escipub.com/american-journal-of-educational-research-and-reviews/ 
While the pupils without a migrant background form a clear majority in grammar school I and in the comprehensive school, with $72 \%$ and $65 \%$ respectively, the distribution is far less even in grammar school II: $49 \%$ of the pupils have no migrant background, $51 \%$ do have a migrant background (first and second generation combined). In the middle school, on the other hand, the school children with a migrant background represent the vast majority, with a share of $89 \%$. This remarkable selection of the student body by type of school can also be observed at the national federal level. The most striking differences in the composition of the student body in Germany continue to exist between secondary modern schools and grammar schools. The share of pupils with a migrant background who attend a secondary modern school (47.8\%) is almost twice as high as that of migrant grammar school pupils (26.4\%) (cf. DESTATIS 2016, p. 87).

Considering this background, we now turn to the question whether the widely varying migrationrelated heterogeneity at the level of the schools exerts any influence on the relationship patterns of the school children. Are the pupils with a migrant background who attend the individual schools embedded in their respective class communities to varying degrees? A look at the strong reciprocal relationships provides first clues here (cf. Table 2):

Following a comparison of the average degree centralities of the strong relationships (reciprocal; > 3) for the three groups at the level of the school, it becomes apparent that the values feature significantly less variation, if the student body is roughly evenly distributed in terms of the attribute "migrant background".

Grammar school II features the smallest differences: Here, pupils have relationships measuring a strength of 2.22 to 2.74 on average. In contrast, there are noticeably greater differences in relation to the average number when we consider grammar school I (1.47 - 3.0) and the middle school (1.47 - 2.27). In the case of these two schools, the ratio of pupils with and without a migrant background is also rather unbalanced. One point worth remarking on here is that, in the case of all schools, the largest group also has the highest average number of ties. This even applies to the middle school, where the vast majority of pupils has a migrant background. In this case, the pupils with a migrant background of the second generation have the highest number of outgoing relationships on average, while pupils without a migrant background have the lowest output degree.

Turning our attention to the E-I Index at the school level next, we can perceive the extent to which the ties also exist between the groups (see Table 2): Within grammar school II, the attribute of having a migrant background does not appear to play a role in the selection of social contacts (E-I Index $=0.001)$. Grammar school I, however, has the highest E-I Index of0.271, though this value can only be assessed as being indicative of mild homophily. Beyond that, the values of the middle school are particularly interesting: The pupils without a migrant background represent the smallest group, and yet they are listed more often by those school children born abroad than vice versa.

The trend that pupils born abroad tend to have more outgoing relationships directed towardsother groups than the other way around is confirmed for all schools (and especially at the two grammar schools studied). Is it possible to interpret this greater sociability of immigrant children as an indicator for a willingness to integrate, which is only partially reciprocated by the pupils in the majority society?

\section{Discussion and outlook}

Informal communication networks of the school children can serve as an indicator for the networking and embedding that takes placeon within the class community in order to investigate the integration of pupils with a migrant background. The initial results of our study reveal that the pupils with a migrant 
Table 2: Distribution of the relationships of the pupils by migrant background at the level of schools (own survey)

\begin{tabular}{|c|c|c|c|c|c|c|}
\hline \multicolumn{7}{|c|}{ Grammar school I (420 pupils) } \\
\hline $\begin{array}{c}\text { E-I Index } \\
-0.271\end{array}$ & $\begin{array}{l}\text { without } \\
\text { migrant } \\
\text { background }\end{array}$ & $\begin{array}{c}\text { migrant } \\
\text { background } \\
2^{\text {nd }} \\
\text { generation }\end{array}$ & $\begin{array}{c}\text { migrant } \\
\text { background } \\
1^{\text {st }} \\
\text { generation }\end{array}$ & $\begin{array}{l}\text { pupils in } \\
\text { total } \\
\text { (in \%) }\end{array}$ & $\begin{array}{l}\text { outdegree } \\
\varnothing \text { per pupil }\end{array}$ & $\begin{array}{c}\text { reciprocal } \\
\text { ties } \\
\text { above 3 } \\
\varnothing \text { per pupil }\end{array}$ \\
\hline $\begin{array}{c}\text { without } \\
\text { migrant } \\
\text { background }\end{array}$ & 8748 & 1936 & 347 & $\begin{array}{c}302 \\
(72 \%)\end{array}$ & 36.53 & 3 \\
\hline $\begin{array}{c}\text { migrant } \\
\text { background } \\
2^{\text {nd }} \\
\text { generation }\end{array}$ & 2203 & 686 & 183 & $\begin{array}{c}84 \\
(20 \%)\end{array}$ & 36.57 & 2.87 \\
\hline $\begin{array}{c}\text { migrant } \\
\text { background } \\
1^{\text {st }} \\
\text { generation }\end{array}$ & 554 & 237 & 82 & $\begin{array}{c}34 \\
(8 \%)\end{array}$ & 25.68 & 1.47 \\
\hline
\end{tabular}

\begin{tabular}{|c|c|c|c|c|c|c|}
\hline \multicolumn{7}{|c|}{ Grammar school II (142 pupils) } \\
\hline $\begin{array}{c}\text { E-I Index } \\
-0.001\end{array}$ & $\begin{array}{c}\text { without } \\
\text { migrant } \\
\text { background }\end{array}$ & $\begin{array}{c}\text { migrant } \\
\text { background } \\
2^{\text {nd }} \\
\text { generation }\end{array}$ & $\begin{array}{c}\text { migrant } \\
\text { background } \\
1^{\text {st }} \\
\text { generation }\end{array}$ & $\begin{array}{c}\text { pupils in } \\
\text { total } \\
\text { (in \%) }\end{array}$ & $\begin{array}{l}\text { outdegree } \\
\varnothing \text { per pupil }\end{array}$ & $\begin{array}{c}\text { reciprocal } \\
\text { ties } \\
\text { above 3 } \\
\varnothing \text { per pupil }\end{array}$ \\
\hline $\begin{array}{c}\text { without } \\
\text { migrant } \\
\text { background }\end{array}$ & 1179 & 667 & 86 & $\begin{array}{c}69 \\
(49 \%)\end{array}$ & 28 & 2.74 \\
\hline $\begin{array}{c}\text { migrant } \\
\text { background } \\
2^{\text {nd }} \\
\text { generation }\end{array}$ & 698 & 719 & 165 & $\begin{array}{c}58 \\
(41 \%)\end{array}$ & 26.34 & 2.22 \\
\hline $\begin{array}{c}\text { migrant } \\
\text { background } \\
1^{\text {st }} \\
\text { generation }\end{array}$ & 145 & 200 & 66 & $\begin{array}{c}15 \\
(10 \%)\end{array}$ & 27.4 & 2.53 \\
\hline
\end{tabular}

\begin{tabular}{|c|c|c|c|c|c|c|}
\hline \multicolumn{7}{|c|}{ Comprehensive school (201 pupils) } \\
\hline $\begin{array}{c}\text { E-I Index } \\
-0.146\end{array}$ & $\begin{array}{l}\text { without } \\
\text { migrant } \\
\text { background }\end{array}$ & $\begin{array}{c}\text { migrant } \\
\text { background } \\
2^{\text {nd }} \\
\text { generation }\end{array}$ & $\begin{array}{c}\text { migrant } \\
\text { background } \\
1^{\text {st }} \\
\text { generation }\end{array}$ & $\begin{array}{l}\text { pupils in } \\
\text { total } \\
\text { (in \%) }\end{array}$ & $\begin{array}{l}\text { outdegree } \\
\varnothing \text { per pupil }\end{array}$ & $\begin{array}{c}\text { reciprocal } \\
\text { ties } \\
\text { above 3 } \\
\varnothing \text { per pupil }\end{array}$ \\
\hline $\begin{array}{c}\text { without } \\
\text { migrant } \\
\text { background }\end{array}$ & 2186 & 697 & 214 & $\begin{array}{c}130 \\
(65 \%)\end{array}$ & 23.82 & 1.98 \\
\hline $\begin{array}{c}\text { migrant } \\
\text { background } \\
2^{\text {nd }} \\
\text { generation }\end{array}$ & 716 & 410 & 48 & $\begin{array}{c}51 \\
(25 \%)\end{array}$ & 23.02 & 1.61 \\
\hline $\begin{array}{c}\text { migrant } \\
\text { background } \\
1^{\text {st }} \\
\text { generation }\end{array}$ & 223 & 83 & 64 & $\begin{array}{c}20 \\
(10 \%)\end{array}$ & 18.5 & 1.2 \\
\hline
\end{tabular}

\begin{tabular}{|c|c|c|c|c|c|c|}
\hline \multicolumn{7}{|c|}{ Middle school (177 pupils) } \\
\hline $\begin{array}{l}\text { E-I Index } \\
-0.044\end{array}$ & $\begin{array}{c}\text { without } \\
\text { migrant } \\
\text { background }\end{array}$ & $\begin{array}{c}\text { migrant } \\
\text { background } \\
2^{\text {nd }} \\
\text { generation }\end{array}$ & $\begin{array}{c}\text { migrant } \\
\text { background } \\
1^{\text {st }} \\
\text { generation }\end{array}$ & $\begin{array}{l}\text { pupils in } \\
\text { total } \\
\text { (in \%) }\end{array}$ & $\begin{array}{l}\text { outdegree } \\
\varnothing \text { per pupil }\end{array}$ & $\begin{array}{c}\text { reciprocal } \\
\text { ties } \\
\text { above } 3 \\
\varnothing \text { per pupil }\end{array}$ \\
\hline $\begin{array}{c}\text { without } \\
\text { migrant } \\
\text { background }\end{array}$ & 44 & 264 & 62 & $\begin{array}{c}19 \\
(11 \%)\end{array}$ & 19.47 & 1.74 \\
\hline $\begin{array}{c}\text { migrant } \\
\text { background } \\
2^{\text {nd }} \\
\text { generation }\end{array}$ & 252 & 1814 & 588 & $\begin{array}{c}108 \\
(61 \%)\end{array}$ & 24.57 & 2.27 \\
\hline $\begin{array}{c}\text { migrant } \\
\text { background } \\
1^{\text {st }} \\
\text { generation }\end{array}$ & 91 & 725 & 306 & $\begin{array}{c}50 \\
(28 \%)\end{array}$ & 22.44 & 1.48 \\
\hline
\end{tabular}


background have almost as many contacts as those without a migrant background. In this context, our sample features only slight differences. It is possible to state that social integration does take place within the peer-topeer networks in the classes.

It is only when we consider the reciprocal ties that we discover that pupils who themselves were born abroad, have fewer mutual relationships than their fellow school children without a migrant background. Outgoing relations are not reciprocated to a significantly greater degree. Possible reasons might be the shorter length of time spent in Germany and/or the frequently associated limited German language skills. Further analyses are required, in order to explore this hypothesis in greater depth.

The measurements of homophily revealed that within our sample the migrant background does not serve as a conclusive characteristic of the pattern of class networks. The pupils are networked with each other regardless of their migrant background, though it did emerge that children and adolescents born abroad, in particular, are far more likely to have outgoing relationships that remain unreciprocated, unlike the other two groups. This result is instructive and necessitates additional analyses.

Moreover, it must be stated that the integration at the level of the class appears to promise greater success, the more balanced the ratio of pupils with and without a migrant background is at the respective schools. In this respect, the composition of the student body at the level of the school proves to be of particular relevance in terms of integration. The type of school (grammar school, middle school or comprehensive school) appears to have a more modest influence in this context than the recruitment of the school children (location, catchment area, school profile, etc.), a result that is particularly noticeable when comparing the two grammar schools we studied. Given this background, the social segregation of the student body, which can frequently be observed, certainly deserves further discussion. Clearly, the division of the students with and without a migrant background is far more pronounced at the level of the school than within the class communities. Contacts and interactions between children and adolescents within the sphere of the school - this is what our first analyses seem to suggest - are largely not linked to migration factors.

In this paper we have presented the initial results of our study. Future investigations will focus in detail, amongst other things, on the issue of the origin of the pupils with a migrant background. For instance, we aim to study in what way the language and the provenance play a part in the selection of social contacts within the school classes. Furthermore, we shall endeavour to analytically correlate the pupils' formal educational success with the degree and type of their embeddedness in the peer-to-peer networks, in an effort to focus the analyses more specifically on the link between formal and informal education.

\section{References}

1 Bastian, M., Heymann, S. \& Jacomy, M. (2009). Gephi: an open source software for explor- ing and manipulating networks. International AAAI Conference on Weblogs and Social Media.

2 Borgatti, S.P., Everett, M.G. \&.Freemann, L. C. (2009). UCINet for Windows. Software for Social Network Analysis. Harvard: Analytic Technologies.

3 Betz, T. (2004). Bildung und soziale Ungleichheit: Lebensweltliche Bildung in (Migranten-) Milieus.

Arbeitspapiere des Zentrums für sozialpädagogische Forschung der Universität Trier. Arbeitspapier II - 16. URL: https://www.unitrier.de/fileadmin/fb1/prof/PAD/SP2/Arbeitspapier e/Arbeitspapier16_bildung_und_sozi ale_ungleichheit.pdf (09.01.2018).

4 Bicer, E., Windzio, M. \& Wingens, M. (2014). Sozialkapital und ethnische Grenzziehungen im Schulkontext, Wiesbaden: VS Verlag für Sozialwissenschaften. 
5 Bundesministerium für Bildung und Forschung (BMBF) (2015). Integration durch Bildung: Initiativen für Chancengerechtigkeit und Teilhabe. URL:

www.bmbf.de/pub/Integration_durch_Bildung.pdf (09.01.2018).

6 Böhm-Kasper, O., Rohlfs, C., Palentien, C., \& Harring, M. (Ed.). (2010). Freundschaften, Cliquen und Jugendkulturen: Peers als Bildungsund Sozialisationsinstanzen. Wiesba- den: VS Verlag für Sozialwissenschaften.

7 Büchner, P. (1994). (Schul-) Kindsein heute zwischen Familie, Schule und außerschulischen Freizeiteinrichtungen. In P. Büchner (Ed.), Kindliche Lebenswelten, Bildung und innerfamiliale Beziehungen (pp. 9-39). München: Juventa.

8 Ceri, F. (2008). Die Bildungsbenachteiligung von Kindern mit Migrationshintergrund: Wel- che Folgen hat der schulische Umgang mit sprachlichen Differenzen auf die Bildungschancen? Herbolzheim: Centaurus Verlag \& Media.

9 DESTATIS (2011). Zensus. 2011: Ausgewählte Ergebnisse.

URL:

https://www.destatis.de/DE/PresseService/Press

e/Pressekonferenzen/2013/Zensus2011/

Pressebroschuere_zensus2011.pdf?

blob=publicationFile $(09.01 .2018)$.

10 DESTATIS (2016). Datenreport 2016. Ein Sozialbericht für die Bundesrepublik Deutschland. URL:

https://www.destatis.de/DE/Publikationen/Datenr eport/Downloads/Datenreport2016.pd f? blob=publicationFile (09.01.2018).

11 DESTATIS (2017). Zahl der Schüler im Schuljahr 2016/2017 um 0,3 \% gestiegen. Pressemitteilung vom 16. März 2017 - 099/17. URL:

12 https://www.destatis.de/DE/PresseService/Press e/Pressemitteilungen/2017/03/PD17_099_211.ht $\mathrm{ml}(09.01 .2018)$.

13 Deutsches PISA-Konsortium (ED.) (2001). PISA 2000. Basiskompetenzen von Schülerin- nen und Schüler im internationalen Vergleich. Opladen: Leske \& Budrich.

14 Esser, H. (2001). Integration und ethnische Schichtung. Mannheim: Mannheimer Zentrum für Europäische Sozialforschung.

15 Esser, H. (2006). Migration, Sprache und Integration. Berlin: WZB.

16 EURYDICE (2004): Integrating Immigrant Children into Schools in Europe. Brussels:
Eurydice.

URL:

http://www.indire.it/lucabas/lkmw_file/euryd ice/Integrating_immigrant_children_2004_E N.pdf (09.01.2018).

17 Fruchtermann, T.M. \& Reingold, E.M. (1991). Graph drawing by force-directed placement.

18 Software: Practice and Experience, 21 (11), 1121164.

19 Harring, M. (2010). Freizeit, Bildung und Peers informelle Bildungsprozesse im Kontext heterogener Freizeitwelten und PeerInteraktionen Jugendlicher. In M. Harring, $\mathrm{O}$. Böhm-Kasper, C. Rohlfs, \& C. Palentien (Ed.), Freundschaften, Cliquen und Jugend- kulturen (S. 21-59). Wiesbaden: VS Verlag für Sozialwissenschaften. https://doi.org/10.1007/978-3-531-92315-4_2

20 Harring, M., Böhm-Kasper, O., Rohlfs, C., \& Palentien C. (2010).. Peers als Bildungs- und Sozialisationsinstanzen - eine Einführung in die Thematik. In M. Harring, O. Böhm- Kasper, C. Rohlfs, \& C. Palentien (Ed.), Freundschaften, Cliquen und Jugendkulturen (S. 21-59). Wiesbaden: VS Verlag für Sozialwissenschaften. https://doi.org/10.1007/978-3-531-92315-4_1

21

22 Klemm, K. \& Zorn, D. (2017). Demographische Rendite adé. Aktuelle Bevölkerungsentwick- lung und Folgen für die allgemeinbildenden Schulen. Gütersloh: Bertelsmann Stiftung. URL: http://www.bertelsmann-

23 stif-

tung.de/fileadmin/files/BSt/Publikationen/GraueP ublikationen/Demographische_Rendit e_ade final.pdf (23.07.2017).

24 Krackhardt, D. \& Stern, R. N. (1988). Informal Networks and Organizational Crises: An Experimental Simulation. Social Psychology Quarterly, 51 (2), 123-140.

25 Krappmann, L. (2010). Prozesse kindlicher Persönlichkeitsentwicklung im Kontext von Gleichaltrigenbeziehungen. In M. Harring, O. Böhm-Kasper, C. Rohlfs, \& C. Palentien (Ed.), Freundschaften, Cliquen und Jugendkulturen, 187-222. VS Verlag für Sozial- wissenschaften. https://doi.org/10.1007/978-3-531-92315-4_10

26 Krappmann, L., \& Oswald, H. (1983). Beziehungsgeflechte und Gruppen von Gleichaltrigen Kindern in der Schule. In F. Neidhardt (Ed.), Gruppensoziologie: Perspektiven und Materialien (pp. 420-450). Wiesbaden: Westdeutscher Verlag. 
Philipp Aufenvenne et al., AJERR, 2018; 3:19

27 OECD (Ed.) (2007). PISA 2006 - Schulleistungen im internationalen Vergleich. Gütersloh: Bertelsmann.

28 McPherson, M., Smith-Lovin, L. \& Cook, J.M. (2001): Birds of a Feather: Homophily in Social Networks. Annual Review of Sociology, 27, 415444.

29 Mitchell, J. C. (1969): The Concept and Use of Social Networks. In: Mitchell, J. C. (ed): Networks in Urban Situations, Manchester: Manchester University Press. 1-50.

30 Parsons, T. (1970). Social Structure and Personality. London: Free Press.

31 Preuss-Lausitz, U. (1992). Ganztägig offene Schulen aufgrund veränderter Kindheit. Diskurs, 1, 6-11.

32 Quenzel, G., \& Hurrelmann, K. (Ed.). (2010). Bildungsverlierer: Neue Ungleichheiten.

33 Wiesbaden: VS Verlag für Sozialwissenaften.

34 Reitz, A. K., Zimmermann, J., Hutteman, J., Specht, J. \& Neyer, F. J. (2014): How Peers Make a Difference: The Role of Peer Groups and Peer Relationships in Personality Development. European Journal of Personality, 28 (3), 279-288.
Statistik aus dem Einwohnermelderegister (Stand: 31.12.2016).

36 Stegbauer, S. (2002). Reziprozität. Einführung in soziale Formen der Gegenseitigkeit. Wies- baden: Westdeutscher Verlag.

37 Steinbrink, M., Schmidt, J.-B. \& Aufenvenne, P. (2013). Soziale Netzwerkanalyse für HumangeographInnen. Einführung in UCINET und NetDraw in fünf Schritten. Potsdam: Universitätsverlag Potsdam.

38 Steinbrink, M., Aufenvenne, P. \& Schmidt, J.-B. (2015). Netzwerk(analys)e in der Geographiedidaktik. In A. Budke, \& Kuckuck, M. (Ed.):Geographiedidaktische Forschungsmethoden (=Praxis Neue Kulturgeographie, Bd. 10). Münster: LIT Verlag, 433- 463.

39 Trappmann, M. (2003). Einfluss von Eigenschaften der Schulumgebung auf die Multiplexität der Verkehrskreise von Kindern: eine Mehrebenenanalyse. Berlin: Wiss. Verl. Berlin.

40 Zeiher, H. J., \& Zeiher, H. (1994). Orte und Zeiten der Kinder: soziales Leben im Alltag von Großstadtkindern. Weinheim: Juventa.

Stadt Osnabrück (2017). Unveröffentlichte

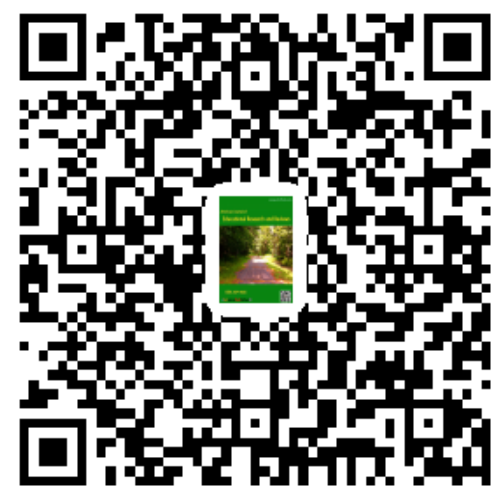

